\title{
Lauryl Phosphate Adsorption in the Flotation of Bastnaesite,
}

\section{$(\mathrm{Ce}, \mathrm{La}) \mathrm{FCO}_{3}$}

\author{
Weiping $\mathrm{Liu}^{1,2}$, Xuming Wang ${ }^{2}$, Hui $\mathrm{Xu}^{1}$, \\ J.D. Miller ${ }^{2 *}$
}

\begin{abstract}
Wetting characteristics and micro-flotation responses of bastnaesite were examined as a function of $\mathrm{pH}$ and at different levels of lauryl phosphate adsorption. Theoretical computations for the bastnaesite-lauryl phosphate system were calculated using the universal force field (UFF) and semiempirical quantum chemical methods. The interaction energy and frontier orbital results correlate remarkably well with the experimental contact angle and micro-flotation test results. The wetting characteristics of bastnaesite with adsorbed collector were examined using both contact angle measurements and molecular dynamics simulations (MDS). The adsorption isotherm at low levels of lauryl phosphate adsorption was established. Finally, the relationship between hydrophobicity and adsorption density was examined by MDS, and compared to the results with octyl hydroxamate at low collector concentrations.
\end{abstract}

Keywords: Lauryl phosphate; Adsorption; Flotation; Bastnaesite; MDS; Contact angle; Avogadro; MOPAC

\section{Introduction}

Rare-earth elements are crucial in many areas of technology including new catalysts for automotive exhaust systems, electronic systems, military applications, medical diagnostic equipment, permanent magnets for computer equipment, etc [1].Bastnaesite is a semi-soluble salt mineral with the characteristics of ionic bonding and limited solubility in water; it contains the cerium subgroup or the lighter rare earth elements [2]. There are two major deposits of bastnaesite in the world, the Mountain Pass deposit in California, USA, and the Bayan Obo deposit in Mongolia, China $[3,4]$. 
As for the flotation of bastnaesite, the main collectors are fatty acids [5] and alkyl hydroxamic acids $[1,4]$. Nevertheless, the use of phosphonate collectors $[6,7]$ and phosphate collectors [8-12] is also reported. Some research results indicate that alkyl phosphates might be better collectors when compared with alkyl phosphonates in the flotation of bastnaesite $[8,9,13]$.

The phosphate collectors P538, P538-La, bastnaesite, and bastnaesite with adsorbed P538 were examined using infrared spectroscopy $[8,9]$. Compared with the infrared spectrum of $\mathrm{P} 538$, the peak of $-\mathrm{P}=\mathrm{O}$ moved to a lower wave number value of $1150 \mathrm{~cm}^{-1}$ in the infrared spectra of both P538-La and bastnaesite with adsorbed $\mathrm{P} 538$. This feature indicates that $-\mathrm{P}=\mathrm{O}$ has a complexation reaction with the $\mathrm{RE}$ cation. The results of ESCA (XPS) measurements of bastnaesite and bastnaesite with adsorbed P538 in Table 1 reveal the concentration of C; P increased the same time, which is expected if a chemical reaction occurs between P538 and the rare earth cations.

Table 1.Surface composition before and after adsorption (\%) [8].

\begin{tabular}{llllllll}
\hline Sample & C & La & Ce & O & F & P & La+Ce \\
\hline Bastnaesite & 34.82 & 2.86 & 3.40 & 53.51 & 5.40 & & 6.26 \\
P538-Bastnaesite & 52.00 & 1.97 & 2.02 & 38.52 & 2.89 & 2.60 & 3.99 \\
\hline
\end{tabular}

Significant adsorption of Flotinor SM15 (an ester of phosphoric acid) on the bastnaesite surface at all $\mathrm{pH}$ ranges was expected from the zeta potential experiments. The results suggest that chemisorption occurs over the alkaline $\mathrm{pH}$ range $(\mathrm{pH}>6.3)$ on the bastnaesite surface, and both physisorption and chemisorption are involved in the acidic $\mathrm{pH}$ range $(\mathrm{pH}<6.3)[12]$.

Recently the surface chemistry characteristics of the potassium lauryl phosphate/bastnaesite system have been reported [13]. The results indicate that potassium lauryl phosphate might be a better collector for bastnaesite when compared with octyl hydroxamate at a low concentration $\left(\leq 5 \times 10^{-5} \mathrm{M}\right)$. However, the fundamental features of potassium lauryl phosphate adsorption are still unknown and are the subject of this paper.

Potassium lauryl phosphate $\left(\mathrm{C}_{12} \mathrm{H}_{26} \mathrm{O}_{4} \mathrm{PK}\right)$ is a weak acid salt. Mono alkyl phosphate is denoted as $\mathrm{ROPO}_{3}{ }^{2-}$, in which $\mathrm{R}$ corresponds to $\mathrm{C}_{12} \mathrm{H}_{25}$. The distribution of the potassium lauryl phosphate species as a function of $\mathrm{pH}$ is summarized in Table 2 [13]. In order to have a fundamental understanding of the competitive adsorption behavior of lauryl phosphate and water at the bastnaesite surface, the semiempirical quantum chemical method was used to calculate the frontier orbital for water, lauryl phosphate species and the bastnaesite surface. Also, the interaction energies between different phosphate species with the bastnaesite surface were 
calculated using the universal force field (UFF) and the semiempirical quantum chemical methods, thereby giving improved understanding of the fundamental aspects of potassium lauryl phosphate adsorption as a function of $\mathrm{pH}$. The results were compared to contact angle and micro-flotation results.

Table 2. The dominant species of lauryl phosphate as a function of $\mathrm{pH}$.

\begin{tabular}{cc}
\hline $\mathrm{pH}$ range & Dominant species \\
\hline$<2.85$ & $\mathrm{ROPO}_{3} \mathrm{H}_{2}$ \\
$2.85-7.35$ & $\mathrm{ROPO}_{3} \mathrm{H}^{-}$ \\
$>7.35$ & $\mathrm{ROPO}_{3}{ }^{2-}$ \\
\hline
\end{tabular}

Good flotation of bastnaesite with potassium lauryl phosphate has been shown to occur at low concentration $\left(\leq 5 \times 10^{-5} \mathrm{M}\right)$ [13]. In this regard, the adsorption of potassium lauryl phosphate at low concentrations was studied, and the results are discussed together with data reported in the literature. Contact angle measurements and MDS were used to investigate the hydrophobic surface state of bastnaesite at different levels of lauryl phosphate adsorption below monolayer coverage. The relationship between contact angle and adsorption density was also established. It is intended that these results will improve the fundamental understanding of the hydrophobic surface state associated with the bastnaesite flotation chemistry. The effective collector species also can be examined in more detail based on UFF and semiempirical quantum chemical interaction energy calculations.

\section{Materials and methods}

\subsection{Sample preparation}

Cola ${ }^{\circledR}$ Fax PME, a solution with $30 w t . \%$ of potassium lauryl phosphate $\left(\mathrm{C}_{12} \mathrm{H}_{26} \mathrm{O}_{4} \mathrm{PK}\right)$ from Colonial Chemical Incorporated Company (South Pittsburg, Tennessee, USA), was used in this research. Bastnaesite samples were from Zagi Mountain, Pakistan.

Bastnaesite samples were dry ground to $-45 \mu \mathrm{m}$ for the adsorption isotherm measurements. The Brunauer-Emmett-Teller (BET) adsorption method was used to evaluate the surface area of the bastnaesite ground samples, using nitrogen gas with a Micromeritics ASAP 2020 analyzer (University of Utah, Salt Lake City, Utah, USA) [1] The surface area of the ground bastnaesite was $0.76 \mathrm{~m}^{2} / \mathrm{g}$.

To prepare the bastnaesite for contact angle measurements with lauryl phosphate adsorption, the bastnaesite surface was cleaned by rinsing with acetone, methanol, then washed many times with copious amounts of deionized water, finally it was dried with high-purity nitrogen. The samples were then treated with nitrogen 
plasma, and dried with ultra high-purity nitrogen gas [1].

\subsection{Adsorption density determinations}

The total organic carbon analyzer (model: TOC-VCPH/CPN) from SHIMADZU corporation (Kyoto, Japan) was used to measure the adsorption density of lauryl phosphate on the bastnaesite surface. The adsorption experiment was done at natural $\mathrm{pH}$ 4.7-6.5, where maximum flotation recovery was found [13]. The following concentrations of potassium lauryl phosphate were prepared for the adsorption experiment, $5 \times 10^{-6} \mathrm{M}, 1 \times 10^{-5} \mathrm{M}, 2 \times 10^{-5} \mathrm{M}, 3 \times 10^{-5} \mathrm{M}, 5 \times 10^{-5} \mathrm{M}$ and $1 \times 10^{-4} \mathrm{M}$. With a solid to liquid ratio of 1:100, bastnaesite powder samples of $0.5 \mathrm{~g}$ (particle size -45 $\mu \mathrm{m})$ were mixed with $50 \mathrm{ml}$ of potassium lauryl phosphate solution. Each time a blank test was also made using ultra pure water. Then the solutions were shaken simultaneously for $4 \mathrm{~h}$ at a speed of $200 \mathrm{rpm}$ on a Barnstead-Lab Line Max Q2000 Orbital Shaker (University of Utah, Salt Lake City, Utah, USA). After filtration, the residual potassium lauryl phosphate in solution was measured. The concentration of potassium lauryl phosphate solution before adsorption was also measured. After that, the adsorption density was calculated according to the amount of adsorbed potassium lauryl phosphate and the surface area of bastnaesite. Further information about the principle of adsorption can be found in the literature $[14,15]$.

\subsection{Contact angle measurements}

The captive bubble and sessile drop contact angles were measured with a Rame-Hart goniometer (Rame-Hart, Succasunna, New Jersey, USA). An air bubble or a drop of water was formed and released from the needle tip, then held and attached on the bastnaesite surface, finally an intermediate contact angle was measured. Five bubbles/water drops were created and measured at different locations on the surface for each specific measurement. Average values of the five measurements were reported. Readers interested about the technique of contact angle measurement and the nature of hydrophobicity and hydrophilicity should consult the relevant literature [16-17].

\subsection{Micro-flotation tests}

A $112 \mathrm{ml}$ column cell having a porous sintered glass bottom was used in the flotation of bastnaesite using potassium lauryl phosphate (Cola ${ }^{\circledR} \mathrm{Fax}$ PME) as collector. The bastnaesite sample ( $100 \times 200$ mesh) of $1 \mathrm{~g}$ was added to the collector solution in each test, and then conditioned in a beaker for $5 \mathrm{~min}$ by magnetic stirring. Then the sample and the solution were transferred to the flotation cell. The flotation tests were conducted for $2 \mathrm{~min}$ using nitrogen at a flow rate of $50 \mathrm{ml} / \mathrm{min}$. Further information about the micro-flotation cell can be found in the literature $[18,19]$. 


\subsection{Universal force field (UFF) and semi-empirical quantum chemical methods}

The universal force field [20] from Avogadro [21] and the semiempirical quantum chemistry program, MOPAC2012 (Molecular Orbital Package) at PM6 level [22-25], were used to model the interactions of the lauryl phosphate species with bastnaesite surfaces.

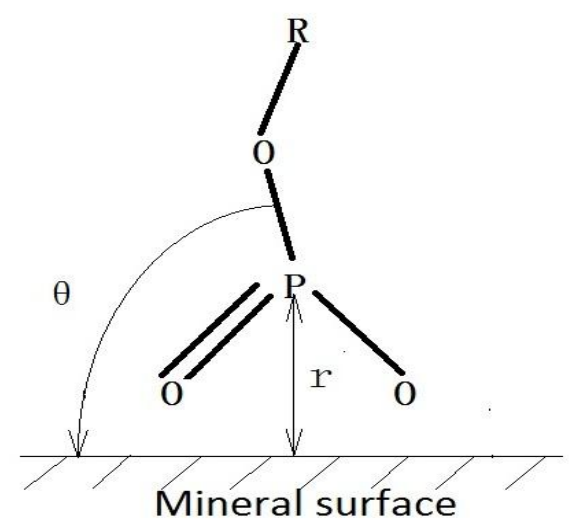

Fig. 1. Schematic representation of the geometry of the adsorption complex.

Lauryl phosphate was placed on the bastnaesite surfaces using the visual molecular dynamics (VMD) molecular graphics tool [26]. The UFF [20] and the semiempirical quantum chemistry program, MOPAC2012 (Molecular Orbital Package) PM6 [22], were used to optimize the bastnaesite-lauryl phosphate complex by varying $r$ and $\theta$ as shown in Fig. 1. Where $r$ indicates the shortest distance between the collector molecule and the mineral surface, and $\theta$ indicates the angle between the alkyl chain in the collector molecule and the mineral surface plane. Thus, the optimized configuration with the optimum distance $r_{\text {opt }}$ and optimum angle $\theta_{\text {opt }}$ were obtained [27].

The interaction energy $(\Delta E)$ of mineral-lauryl phosphate, for both the UFF and PM6 methods, was computed using the following equation:

$$
\Delta E=E_{\text {complex }}-\left(E_{\text {mineral surface }}+E_{\text {collector }}\right)
$$

$E_{\text {complex }}, E_{\text {mineral surface, }}$ and $E_{\text {collector }}$ are the energies of the optimized mineralcollector complex, mineral, and collector (lauryl phosphate), separately. It should be noticed that smaller values of the interaction energy $(\Delta E)$ indicate stronger interactions between the mineral surface and the collector. More about the principle and application of UFF and the semiempirical quantum chemical methods can be found in the literature $[20,28]$. 


\subsection{Molecular Dynamics Simulations (MDS)}

The MDS program Amber 14 [29] was used for the simulation of bastnaesite surfaces in the presence of lauryl phosphate. The total energy in MDS is based on the evaluation of the appropriate energy terms for the interaction between every atom in the system. As shown in Eq. (2), this total energy in MDS includes the Coulombic (electrostatic) energy, the short-range energy (van der Waals energy term), the bond stretch energy, and the angle bend energy [30].

$$
E_{\text {total }}=E_{\text {Coulombic }}+E_{V D W}+E_{\text {bond stretch }}+E_{\text {angle bend }}
$$

Many molecular water models have been developed. From those models, proposed is the rigid extended simple point charge (SPC/E) water model. This model has the closest average configurational energy to the experimental value (-41.6 $\mathrm{kJ} / \mathrm{mol}$ ) [31,32]. The SPC/E water model was used for measuring the simulated contact angles in this study [33].

As shown in Eq. (3), the Coulombic energy is inversely proportional to the distance of separation $r_{i j}$. The terms $q_{i}$ and $q_{j}$ are partial charges for atoms $i$ and $j$. The term $e$ and $\varepsilon_{0}$ are the charge of an electron and the dielectric permittivity of a vacuum $\left(8.85419 \times 10^{-12} \mathrm{~F} / \mathrm{m}\right)$, respectively.

$$
E_{\text {Coulombic }}=\frac{e^{2}}{4 \pi \varepsilon_{0}} \sum_{i \neq j} \frac{q_{i} q_{j}}{r_{i j}}
$$

The van der Waals energy term is represented by the conventional Lennard-Jones (12-6) function in Eq. (4) [34]. The terms $\varepsilon_{i j}$ and $r_{m, i j}$ are the depth of the potential well and the distance of the minimum potential, respectively.

$$
E_{V D W}=\sum_{i \neq j} \varepsilon_{i j}\left[\left(\frac{r_{m, i j}}{r_{i j}}\right)^{12}-2\left(\frac{r_{m, i j}}{r_{i j}}\right)^{6}\right]
$$

Concerning the unlike atoms, the distance parameter $r_{m, i j}$ and energy parameter $\varepsilon_{i j}$ were calculated by the arithmetic mean rule and the geometric mean rule, respectively [20].

$$
\begin{gathered}
r_{m, i j}=\frac{1}{2}\left(r_{m, i}+r_{m, j}\right) \\
\varepsilon_{i j}=\sqrt{\varepsilon_{i} \varepsilon_{j}}
\end{gathered}
$$

As for the simulation, a simple cubic cell was constructed. This cubic cell 
included water molecules using the extended simple point charge (SPC/E) model [35], and bastnaesite based on the lattice parameters provided by the American Mineralogist Crystal Structure Database [36]. The bastnaesite cleavage (100) surface was used for simulation [1,27], and the periodic boundary condition was introduced. Tables 3 and 4 list the number of atoms in MDS and the intermolecular potential parameters. Table 5 shows the charge parameters for the lauryl phosphate collector. The charges and force field parameters for lauryl phosphate molecules were calculated using the Gaussian 09 program [37] at the HF/6-31G(D) level. Three levels of lauryl phosphate coverage, $8.3 \%, 25 \%$ and $50 \%$, were investigated.

An NVT [moles (N), volume (V) and temperature $(T)$ are conserved] ensemble using Hoover's thermostat was introduced in this simulation [38]. The Leap-frog method with a time step of $2 \mathrm{fs}$ (femtoseconds) was used to integrate the particle motion. The Ewald sum was used to represent the electrostatic interactions. A final simulation time of $1 \mathrm{~ns}$ (nanosecond) ( $5 \times 10^{5}$ steps) was performed after a $500 \mathrm{ps}$ (picosecond) equilibration period.

Table 3. Number of atoms at the bastnaesite surface for water drop contact angle measurements with lauryl phosphate adsorption.

\begin{tabular}{cc}
\hline Species & Number of atoms \\
\hline Cerium & 5100 \\
Fluorine & 5100 \\
Carbon & 5100 \\
Oxygen & 15300 \\
$8.3 \%$ lauryl phosphate coverage & 36 molecules \\
$25 \%$ lauryl phosphate coverage & 106 molecules \\
$50 \%$ lauryl phosphate coverage & 212 molecules \\
\hline
\end{tabular}

Table 4. Parameters for water interactions at the bastnaesite surface with absorbed lauryl phosphate.

\begin{tabular}{ccccc}
\hline Species & Charge $[\mathrm{e}]$ & $\varepsilon[\mathrm{kcal} / \mathrm{mol}]$ & $\mathrm{r}[\AA]$ & Reference \\
\hline Cerium & 3 & 0.007 & 4.4470 & {$[1]$} \\
Fluorine & -1 & 0.1673 & 3.5279 & {$[39]$} \\
Bastnaesite carbon & 0.883 & 0.0403 & 3.4879 & {$[40,41]$} \\
Bastnaesite oxygen & -0.961 & 0.1554 & 3.5536 & {$[35]$} \\
Lauryl phosphate carbon & & 0.1094 & 3.8160 & \\
Lauryl phosphate oxygen & & 0.2104 & 3.442 & Calculated \\
Lauryl phosphate phosphorous & & 0.2000 & 4.2000 & from Gaussian \\
Lauryl phosphate hydrogen & & 0.0157 & 2.2112 & \\
Water oxygen & -0.8476 & 0.1554 & 3.1659 & {$[35]$} \\
Water hydrogen & 0.4238 & 0 & 0 & {$[35]$} \\
\hline
\end{tabular}


Table 5. Gaussian calculated charge parameters for lauryl phosphate.

\begin{tabular}{|c|c|c|c|}
\hline Atom name & Charge & Atom name & Charge \\
\hline C & 0.298849 & $\mathrm{H}$ & -0.000320 \\
\hline C & 0.009229 & $\mathrm{H}$ & 0.010489 \\
\hline C & -0.100366 & $\mathrm{H}$ & 0.002642 \\
\hline C & 0.012063 & $\mathrm{H}$ & -0.009370 \\
\hline C & 0.045456 & $\mathrm{H}$ & 0.004752 \\
\hline C & -0.071550 & $\mathrm{H}$ & -0.027899 \\
\hline C & 0.007257 & $\mathrm{H}$ & -0.007144 \\
\hline C & 0.098564 & $\mathrm{H}$ & 0.033687 \\
\hline C & -0.157994 & $\mathrm{H}$ & 0.037460 \\
\hline C & -0.032325 & $\mathrm{H}$ & 0.015216 \\
\hline C & 0.188546 & $\mathrm{H}$ & 0.014054 \\
\hline C & -0.366161 & $\mathrm{H}$ & -0.020431 \\
\hline $\mathrm{H}$ & 0.425456 & $\mathrm{H}$ & -0.015202 \\
\hline $\mathrm{H}$ & -0.011516 & $\mathrm{H}$ & 0.080477 \\
\hline $\mathrm{H}$ & -0.004198 & $\mathrm{H}$ & 0.079537 \\
\hline $\mathrm{H}$ & 0.000221 & $\mathrm{H}$ & 0.082171 \\
\hline $\mathrm{H}$ & 0.020706 & 0 & -0.853735 \\
\hline $\mathrm{H}$ & 0.014384 & 0 & -0.804467 \\
\hline $\mathrm{H}$ & 0.013003 & 0 & -0.735303 \\
\hline $\mathrm{H}$ & -0.013175 & 0 & -0.583075 \\
\hline $\mathrm{H}$ & 0.000258 & $P$ & 1.314099 \\
\hline $\mathrm{H}$ & 0.005655 & & \\
\hline
\end{tabular}

\section{Results and discussions}

\subsection{Interaction energy calculation using UFF and PM6}

As shown in Table 6, the UFF optimized distances $\left(r_{\text {opt }}\right)$ and optimized angles $\left(\vartheta_{\text {opt }}\right)$ for lauryl phosphate absorbed at the (100) bastnaesite surface are listed. It should be further noticed that in Table $6 r$ is defined as the distance of phosphorus ( $P$ in the $-\mathrm{PO}_{4}-$ functional group) from a reference cerium atom in the lauryl phosphate molecule at the bastnaesite surface. Thus the optimized distances $\left(r_{\text {opt }}\right)$ presented in Table 6 appear to be higher than the optimized distances in Fig. 2. 
Table 6. UFF optimized structures [ $\vartheta_{\text {opt }}$ (in degrees) and $r_{\text {opt }}$ (in angstrom units)] for lauryl phosphate adsorbed at the (100) bastnaesite surface.

\begin{tabular}{ccccccc}
\hline \multirow{2}{*}{ Method } & \multicolumn{2}{c}{$\mathrm{ROPO}_{3} \mathrm{H}_{2}$} & \multicolumn{2}{c}{$\mathrm{ROPO}_{3} \mathrm{H}^{-}$} & \multicolumn{2}{c}{$\mathrm{ROPO}_{3}{ }^{2-}$} \\
\cline { 2 - 7 } & $\vartheta_{\text {opt }}$ & $r_{\text {opt }}$ & $\vartheta_{\text {opt }}$ & $r_{\text {opt }}$ & $\vartheta_{\text {opt }}$ & $r_{\text {opt }}$ \\
\hline UFF & 109.49 & 3.16 & 101.57 & 3.17 & 100.56 & 3.22 \\
\hline
\end{tabular}

The UFF optimized structures of the bastnaesite-lauryl phosphate complexes are shown in Figs. $2 \mathrm{a}, 2 \mathrm{~b}$, and $2 \mathrm{c}$ for $\mathrm{ROPO}_{3} \mathrm{H}_{2}, \mathrm{ROPO}_{3} \mathrm{H}^{-}$, and $\mathrm{ROPO}_{3}{ }^{2-}$, separately. As shown in Fig. 2, the $\mathrm{O}-\mathrm{Ce}$ distance between the phosphate functional group and surface $\mathrm{Ce}$ atoms is around $3 \mathrm{~A}^{\circ}$, and $\mathrm{ROPO}_{3} \mathrm{H}^{-}$has the shortest distance (3.04 $\mathrm{A}$ ) compared with the two other collector species.

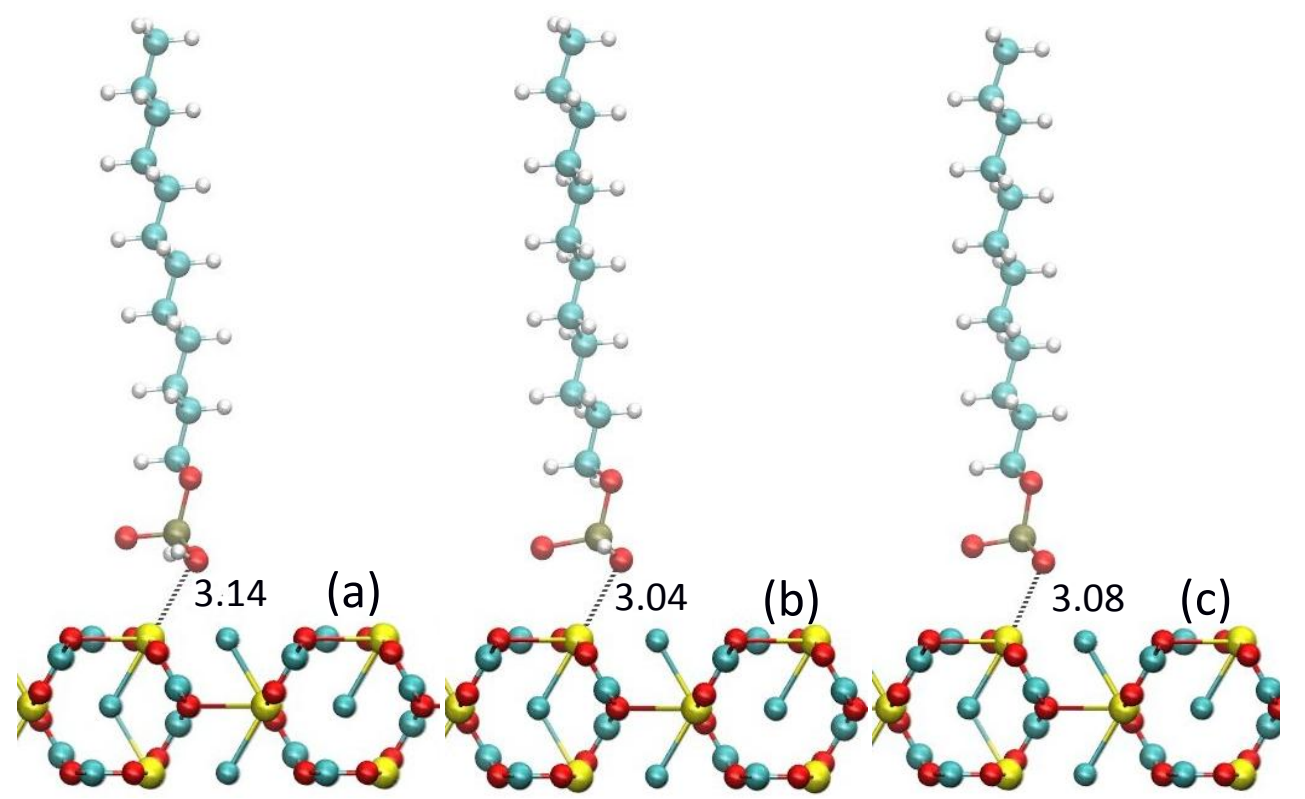

Fig. 2. UFF optimized complex of lauryl phosphate species at the bastnaesite (100) surface. White: hydrogen; red: oxygen; cyan: carbon; yellow: cerium; tan: phosphorus; pink: fluorine (a) $\mathrm{ROPO}_{3} \mathrm{H}_{2}$, (b) $\mathrm{ROPO}_{3} \mathrm{H}^{-}$, and (c) $\mathrm{ROPO}_{3}{ }^{2-}$.

Table 7. UFF/ PM6 interaction energies $(\mathrm{kJ} / \mathrm{mol})$ of lauryl phosphate species adsorption onto bastnaesite.

\begin{tabular}{cccc}
\hline Method & $\mathrm{ROPO}_{3} \mathrm{H}_{2}$ & $\mathrm{ROPO}_{3} \mathrm{H}^{-}$ & $\mathrm{ROPO}_{3}{ }^{2-}$ \\
\hline UFF & -787 & -1373 & -786 \\
PM6 & 15 & -515 & 188 \\
\hline
\end{tabular}

The interaction energies computed by the PM6 method were of the same order as the UFF interaction energies, and the results are summarized together with the UFF method results in Table 7. Based on the relative values of the corresponding interaction energies between the phosphate species and bastnaesite, it is suggested that the order of the bastnaesite flotation response with the lauryl phosphate species should be ROPO $\mathrm{H}^{-}>\mathrm{ROPO}_{3} \mathrm{H}_{2}>\mathrm{ROPO}_{3}{ }^{2-}$. 
Table 8. Energy difference (eV) between frontier orbitals of bastnaesite, $\mathrm{ROPO}_{3} \mathrm{H}^{-}, \mathrm{ROPO}_{3} \mathrm{H}_{2}$,

\begin{tabular}{cccc}
\multicolumn{4}{c}{$\mathrm{ROPO}_{3}{ }^{2-}$, and water. } \\
\hline & $\mathrm{HOMO}$ & LUMO & Difference \\
\hline Bastnaesite & -5.52 & -3.32 & \\
$\mathrm{ROPO}_{3} \mathrm{H}_{2}$ & -10.92 & 0.62 & 6.14 \\
$\mathrm{ROPO}_{3} \mathrm{H}^{-}$ & -6.11 & 5.41 & 2.79 \\
$\mathrm{ROPO}_{3}{ }^{2-}$ & -0.30 & 6.42 & 3.02 \\
Water & -11.90 & 4.07 & 8.58 \\
\hline
\end{tabular}

The frontier orbitals of bastnaesite, the phosphate species and water were compared using MOPAC2012 at the accuracy level of PM6. The reactivity is calculated by comparing the difference between bastnaesite's HOMO (the highest occupied molecular orbital)/LUMO (the lowest unoccupied molecular orbital) and the phosphate species/water's LUMO/HOMO. The smaller value of the absolute difference between these frontier orbitals indicates stronger reactivity of the phosphate species/water toward the bastnaesite surface. As shown in Table 8, these results indicate that $\mathrm{ROPO}_{3} \mathrm{H}^{-}$has greater reactivity with bastnaesite (the smallest difference of $2.79 \mathrm{eV}$ ) when compared to the others. Water, however, has less reactivity than all the phosphate species, which indicates that the phosphate species can replace water at the bastnaesite surface, and in this way a hydrophobic surface state is formed.

Captive bubble contact angle and micro-flotation results of bastnaesite with three collector species $\mathrm{ROPO}_{3} \mathrm{H}_{2}, \mathrm{ROPO}_{3} \mathrm{H}^{-}$, and $\mathrm{ROPO}_{3}{ }^{2-}$ are presented in Fig. 3. $\mathrm{ROPO}_{3} \mathrm{H}^{-}$responds most favorably, and $\mathrm{ROPO}_{3}{ }^{2-}$ the least favorably. The order of the captive bubble contact angles and flotation responses for bastnaesite among the three collector species were thus observed to be $\mathrm{ROPO}_{3} \mathrm{H}^{-}>\mathrm{ROPO}_{3} \mathrm{H}_{2}>\mathrm{ROPO}_{3}{ }^{2-}$.

It should be mentioned that $\mathrm{ROPO}_{3} \mathrm{H}_{2}$ is shown to have better reactivity with bastnaesite than $\mathrm{ROPO}_{3}{ }^{2-}$, according to the interaction energy results of $\mathrm{ROPO}_{3} \mathrm{H}_{2}$ and $\mathrm{ROPO}_{3}{ }^{2-}$ from UFF (-787 and $-786 \mathrm{~kJ} / \mathrm{mol}$ ), and especially from the PM6 level (15 and $188 \mathrm{~kJ} / \mathrm{mol}$ ). However, these results are not in accord with the frontier orbital results in Table 8, which suggest that $\mathrm{ROPO}_{3}{ }^{2-}$ has better reactivity (difference of $3.02 \mathrm{eV}$ ) than $\mathrm{ROPO}_{3} \mathrm{H}_{2}$ (difference of $6.14 \mathrm{eV}$ ). The reason is still unknown, however, it is still significant given that the interaction energy results have such good agreement with the contact angle and micro-flotation results in Fig. 3 and Fig. 4. The frontier orbital results in Table 8 also confirmed that the lauryl phosphate species can replace water on the bastnaesite surface. 


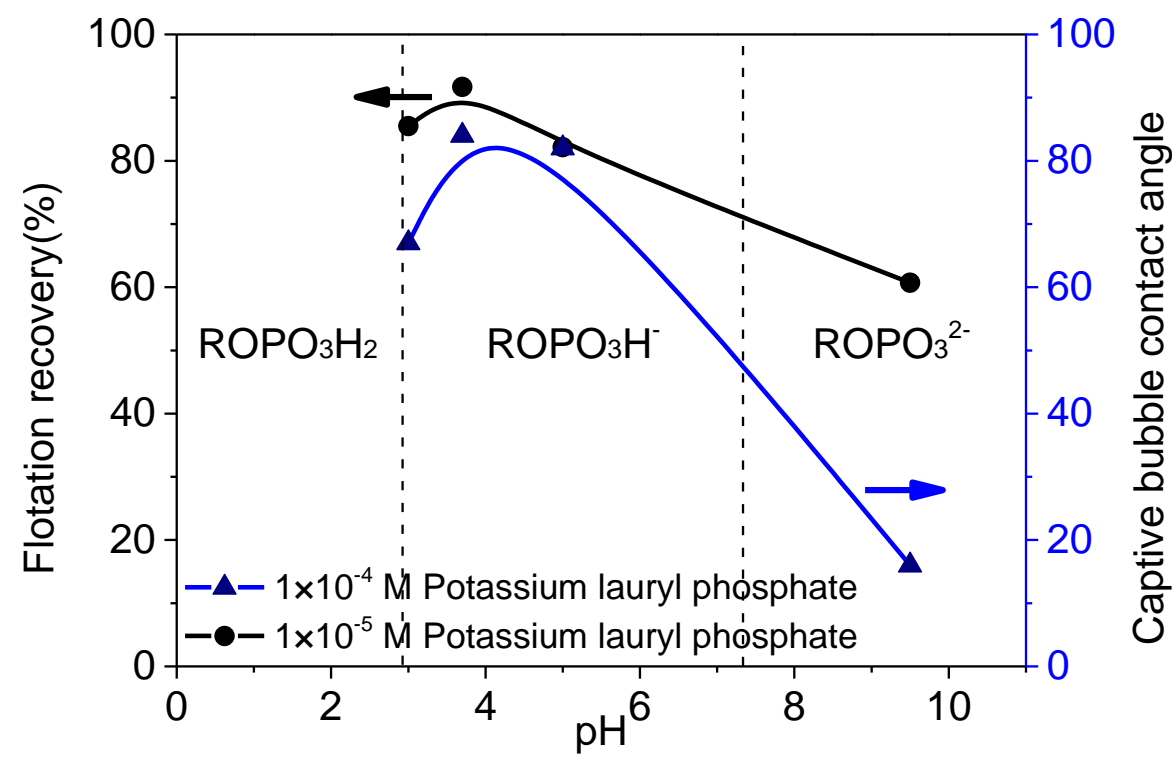

Fig. 3. Captive bubble contact angle and flotation results for bastnaesite with potassium lauryl phosphate collector as a function of $\mathrm{pH}$.

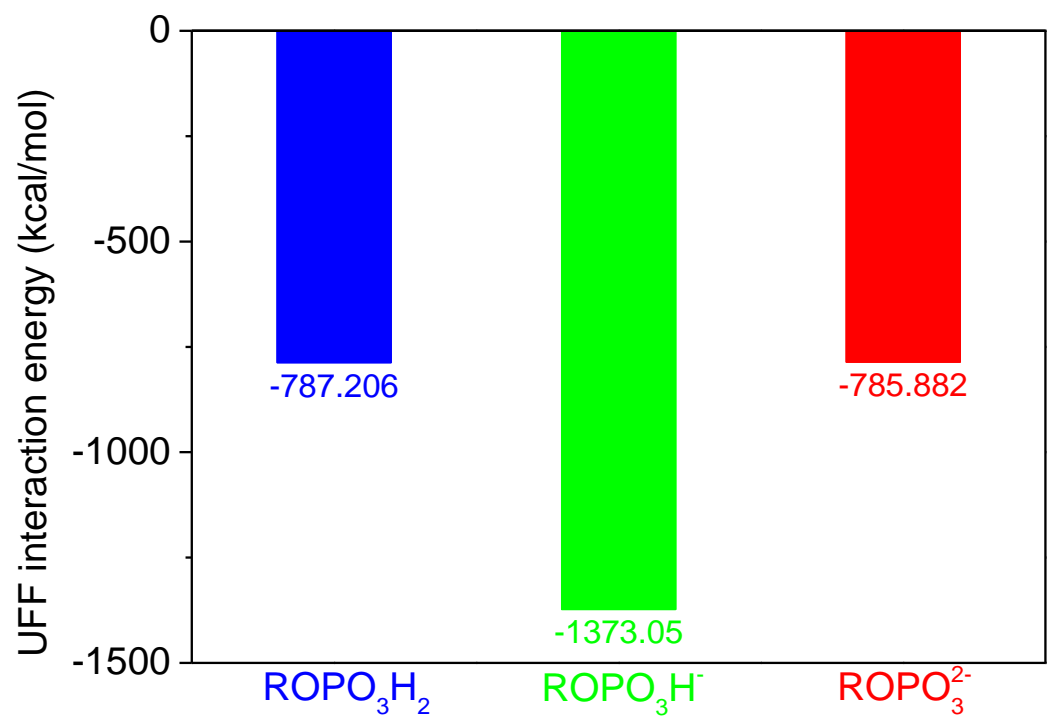

(a) 


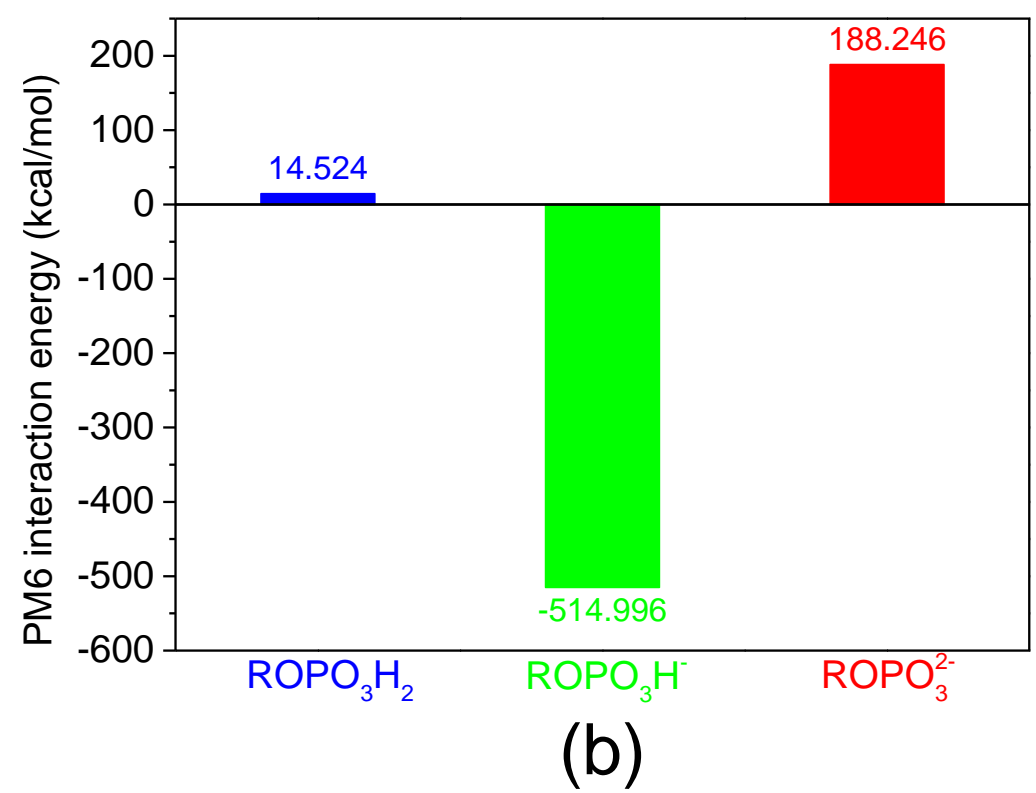

Fig. 4(a). UFF interaction energy and (b) PM6 interaction energy of lauryl phosphate species on a bastnaesite (100) surface.

The interaction energies (computed by both UFF and PM6) of the lauryl phosphate species on a bastnaesite (100) surface are plotted in Figs. 4a and 4b, respectively. The relative order of interaction energy of the lauryl phosphate species as predicted from theoretical consideration agrees well with the experimental contact angle and micro-flotation results (Fig. 3). Also, the results confirm the use of UFF and semiempirical quantum analyses as advanced tools to explain surface chemistry experimental results, and even to predict the potentially reactive collector species for flotation, which has been observed by other researchers $[27,42-44]$.

\subsection{Lauryl phosphate adsorption isotherm}

It is expected that a strong chemisorption reaction occurs at a low concentration of lauryl phosphate. As shown in Fig. 5, the vertical monolayer adsorption density of $8.46 \mu \mathrm{mol} / \mathrm{m}^{2}$ occurs at a potassium lauryl phosphate concentration of about $2.5 \times$ $10^{-5} \mathrm{M}$, which is based on the phosphate group cross sectional area of $19.63 \AA^{2}$. Because of the strong interaction of lauryl phosphate with RE sites at the bastnaesite surface, adsorption can be described by traditional analysis, with the formation of a chemisorbed monolayer followed by surface precipitated multilayers of the RE lauryl phosphate complex, to account for the hydrophobic surface state.

Another explanation [45] for collector adsorption can be considered. In this case the lauryl phosphate might adsorb as bilayer patches until half the surface is covered and that during air bubble contact the bilayer is reorganized to create a monolayer as film rupture occurs and bubble attachment is stabilized. At the vertical monolayer 
concentration of about $2.5 \times 10^{-5} \mathrm{M}$, half of the mineral surface is covered with a self assembled bilayer or close packed structure of lauryl phosphate which is reorganized to a monolayer upon contact and attachment with an air bubble. Below this concentration, the uncovered mineral surface can interact with water molecules and this natural hydrophobic state accounts for the modest contact angle of $45^{\circ}$. See Fig. 6.

In either case, the contact angle is expected to increase with increasing lauryl phosphate adsorption as more of the mineral surface is covered.

Because of the strong adsorption of lauryl phosphate by the bastnaesite surface at low concentration, chemisorption is expected. IR spectra, ESCA (XPS) $[8,9]$ and zeta potential data [12] suggest that chemisorption occurs between the phosphate collector and the bastnaesite surface. The bastnaesite surface under vertical monolayer concentration still maintains its hydrophobic state after washing with acetone, alcohol and DI water. Further evidence for chemisorption of lauryl phosphate needs to be provided.

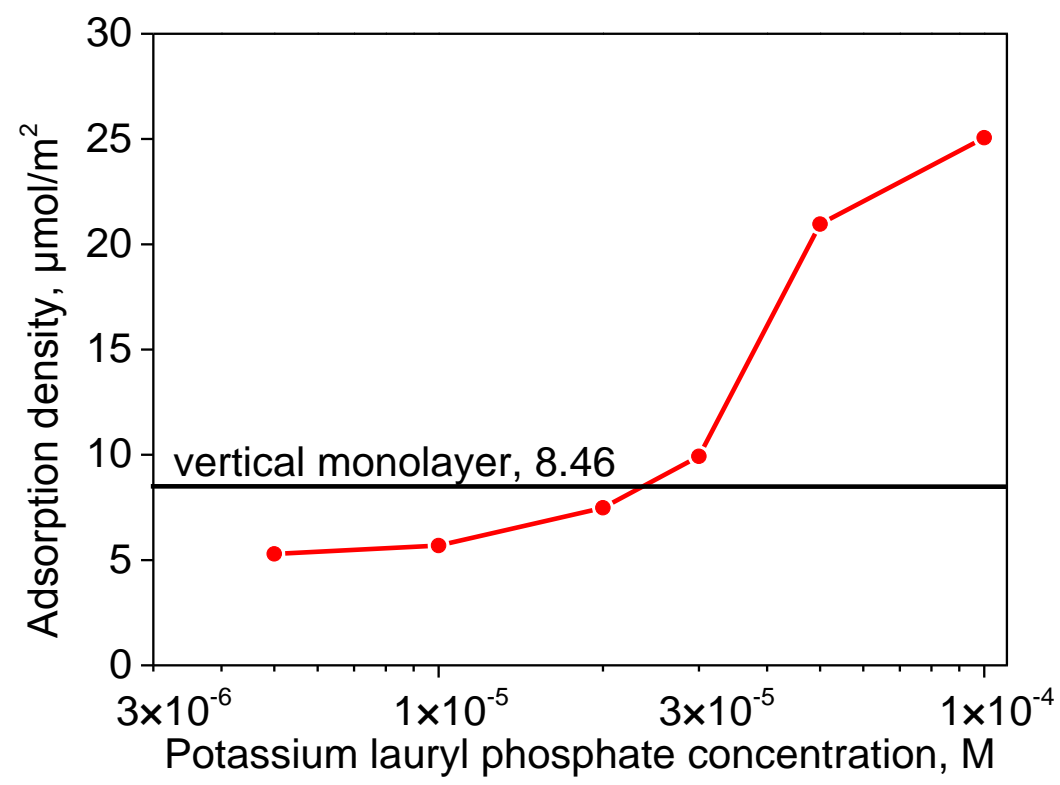

Fig. 5. Lauryl phosphate isotherm at the bastnaesite surface (natural pH 4.7-6.5).

The behavior of monolayers of mono phosphates in solutions containing rare earth cations has been studied through pressure-area relationships and radiometrical analysis of films [46]. Mono alkyl phosphate appeared to have remarkably reduced limiting molecular areas in the presence of rare earth ions. This phenomenon suggested that some esters were pulled out of the surface to form a "sandwich layer" with the metal ion in the middle in the solution. Dimerized quarter-potassium salt also formed under certain conditions. Therefore, it is expected that one cerium ion (or $\mathrm{La}^{3+}$ ) can interact with as many as three phosphate molecules based on the 
reaction of phosphate with RE cations. However, the adsorption is limited by the phosphate cross sectional area, together with the different coexisting phosphate species; not every cerium atom at the surface can accommodate three phosphate molecules.

It should be noted that $\mathrm{pH}$ 4.7-6.5 is the region where $\mathrm{ROPO}_{3} \mathrm{H}^{-}$is the dominant species [13]. The cerium surface site density is calculated to be $4.74 \mu \mathrm{mol} / \mathrm{m}^{2}$ [47]. Thus, an adsorption density of about $8.46 \mu \mathrm{mol} / \mathrm{m}^{2}$ for a vertical monolayer of lauryl phosphate, corresponds to a ratio of about 2 lauryl phosphate molecules for each cerium at the bastnaesite surface. Above the monolayer coverage, multi-layer physisorption of lauryl phosphate occurs at the bastnaesite surface. The physisorption may happen through hydrophobic interaction of hydrocarbon chains or hydrogen bonding as the driving force. From bastnaesite speciation distribution diagrams [48], aqueous $\mathrm{Ce}^{3+}, \mathrm{CeF}^{2+}, \mathrm{CeF}_{2}{ }^{+}$and $\mathrm{CeCO}_{3}{ }^{+}$are available in the system at $\mathrm{pH}$ 4.7-6.5. An excess of lauryl phosphate is present in the high potassium lauryl phosphate concentration solution, and thus form cerium (or other RE cations) lauryl phosphate complexes. Consequently, surface precipitation of anionic lauryl phosphate species, as well as cerium lauryl phosphate, may occur with nucleation and growth of multi-layers of the cerium lauryl phosphate.

\subsection{Contact angle of bastnaesite at low levels of lauryl phosphate adsorption}

Contact angle measurements were made on the bastnaesite surface with adsorbed lauryl phosphate at low levels (below vertical monolayer coverage) by the sessile drop method. The results are shown together with the micro-flotation results in Fig. 6. It can be noted that the contact angle and flotation results increase with an increase in potassium lauryl phosphate concentration, which indicates stronger hydrophobicity of the bastnaesite surface. Also, the contact angle and flotation results increase with an increase of the adsorption density from Fig. 5, as expected. Based on the sessile drop contact angle, micro-flotation, and adsorption density results, it is expected that full monolayer coverage is achieved at a lauryl phosphate concentration of about $2.5 \times 10^{-5} \mathrm{M}$ (contact angle $=50^{\circ}$, adsorption density for monolayer coverage $=8.46 \mu \mathrm{mol} / \mathrm{m}^{2}$ ). Above this point multilayer adsorption occurs. 


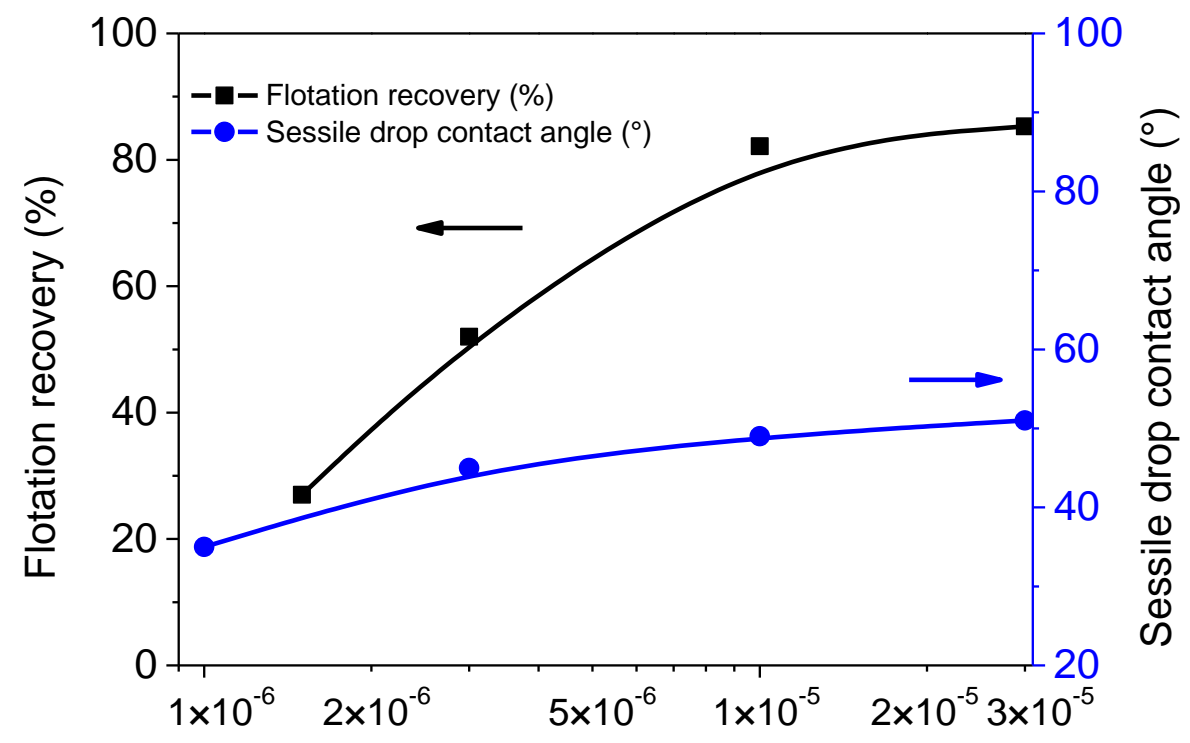

Potassium lauryl phosphate concentration (M)

Fig. 6. Contact angle and flotation results for bastnaesite with potassium lauryl phosphate at natural $\mathrm{pH}$ 4.7-6.0.

\subsection{Wetting characteristics of bastnaesite with lauryl phosphate adsorption}

In order to compare with hydroxamate acid at the bastnaesite surface with the same adsorption coverage [1], one water drop on the three levels of lauryl phosphate coverage at the bastnaesite surface, $8.3 \%, 25 \%$, and $50 \%$, were examined for MD contact angle simulations. 

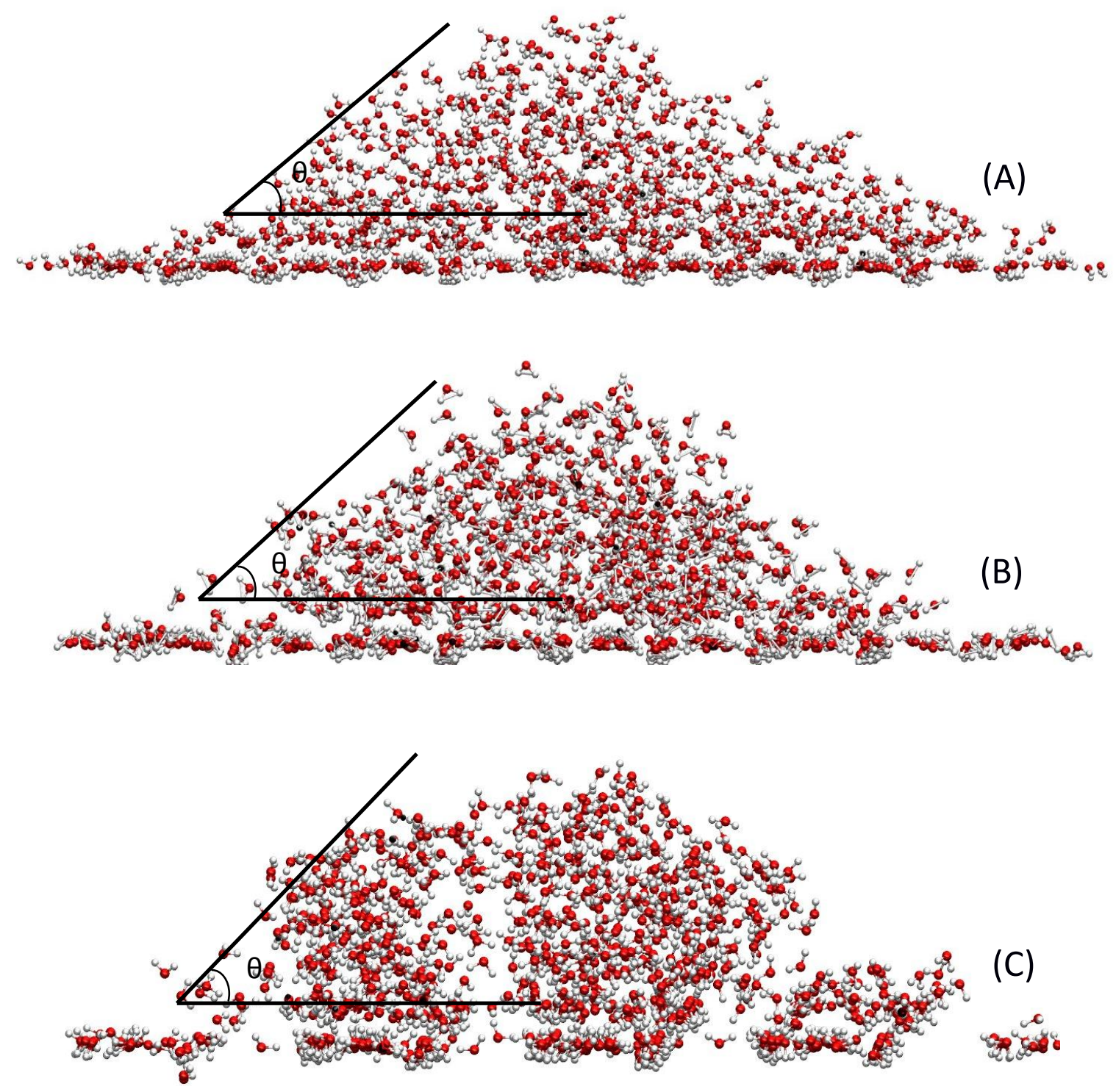

(C)

30

Fig. 7. Visualization of the two-dimensional water density analysis for a water droplet after 1 ns at the bastnaesite surface with different levels of lauryl phosphate coverage: (A) $8.3 \%$, (B) $25 \%$, and (C) $50 \%$.

Fig.7 shows the two-dimensional water density distribution maps of the bastnaesite surface with different levels of lauryl phosphate coverage (lauryl phosphate molecules are transparent). The contact angles $(\theta)$ were determined to be $41^{\circ}, 43^{\circ}, 45^{\circ}$ at the lauryl phosphate coverages of $8.3 \%, 25 \%, 50 \%$ respectively. From Table 9, it can be seen that the $8.3 \%, 25 \%$ and $50 \%$ lauryl phosphate coverages correspond to adsorption densities of $1.05,2.11,4.23 \mu \mathrm{mol} / \mathrm{m}^{2}$, respectively. These results are in good agreement with the experimental sessile drop contact angle values in Fig. 6. 
Table 9. Contact angle results from MDS.

\begin{tabular}{cccc}
\hline Surface coverage (\%) & Concentration $(\mathrm{mol} / \mathrm{l})$ & Adsorption density $\left(\mu \mathrm{mol} / \mathrm{m}^{2}\right)$ & MDS contact angle $(\theta)$ \\
\hline 8.3 & $2 \times 10^{-6}$ & 1.05 & $41^{\circ}$ \\
25 & $6 \times 10^{-6}$ & 2.11 & $43^{\circ}$ \\
50 & $1.2 \times 10^{-5}$ & 4.23 & $45^{\circ}$ \\
\hline
\end{tabular}

Perhaps unexpectedly, it is noticed that the MDS contact angle in Table 9 and the sessile drop contact angle in Fig. 6 increased slightly after the concentration was increased beyond $2 \times 10^{-6} \mathrm{~mol} / \mathrm{l}(8.3 \%$ coverage). This indicates the substantial hydrophobicity of potassium lauryl phosphate at low concentration/adsorption coverage. It is somewhat surprising that such a strong flotation response was observed for a contact angle of less than $50^{\circ}$. Compared with the MDS results of octyl hydroxamate acid at the same adsorption coverage (8.3\% coverage) [1], which is $0^{\circ}$, the MDS result of $41^{\circ}$ at $8.3 \%$ coverage of lauryl phosphate in this study supports the suggestion that potassium lauryl phosphate might be a better collector for bastnaesite than octyl hydroxamate at low concentration $\left(\leq 5 \times 10^{-5} \mathrm{M}\right)$ [13].

\section{Summary and conclusions}

Captive bubble contact angle measurements, micro-flotation results and theoretical computations indicate that the $\mathrm{C}_{12} \mathrm{H}_{25} \mathrm{OPO}_{3} \mathrm{H}^{-}$species of lauryl phosphate may adsorb and be responsible for the bastnaesite hydrophobic surface state. Subsequently, the adsorption density of potassium lauryl phosphate at low concentration was established, and surface chemistry characteristics were analyzed by experimental sessile drop contact angle measurements, micro-flotation and MDS contact angles. The correlation between the experimental results and molecular dynamics simulated contact angles, together with the molecular dynamics simulated contact angle comparison with the hydroxamate acid results reported in reference [1], suggest that potassium lauryl phosphate might be a better collector for bastnaesite when compared with octyl hydroxamate at low concentration $\left(\leq 5 \times 10^{-5} \mathrm{M}\right)$. Further research is in progress.

Conclusions include the following points at this time:

1.Interaction energy results from both UFF and semiempirical quantum chemical methods agree with the order of contact angle measurements and micro-flotation results for bastnaesite with the three collector species, which were observed to be $\mathrm{C}_{12} \mathrm{H}_{25} \mathrm{OPO}_{3} \mathrm{H}^{-}>\mathrm{C}_{12} \mathrm{H}_{25} \mathrm{OPO}_{3} \mathrm{H}_{2}>\mathrm{C}_{12} \mathrm{H}_{25} \mathrm{OPO}_{3}{ }^{2-}$. The frontier orbital absolute difference of the bastnaesite, phosphate species and water, confirm that the phosphate species can replace the water on the bastnaesite surface. The results also confirm that the UFF and semiempirical quantum chemical methods are advanced tools which can explain, and even predict potential reagents which can be used as collectors in 
flotation.

2. Adsorption density measurements of lauryl phosphate have been done using high sensitivity TOC analysis, which show that the adsorption density increases with increasing lauryl phosphate concentration. Monolayer adsorption occurs at about $2.5 \times 10^{-5} \mathrm{M}$ of potassium lauryl phosphate, considering the phosphate cross sectional area to define the monolayer condition. Below monolayer coverage, the chemisorption of lauryl phosphate is expected to occur at the bastnaesite surface. An alternative explanation is that a bilayer or close packed structures of lauryl phosphate self-assemblies $\left(2.5 \times 10^{-5} \mathrm{M}\right)$ cover half of the bastnaesite surface, and then a full monolayer coverage is formed upon contact and attachment with an air bubble.

3. Sessile drop contact angle measurements and micro-flotation results increase with an increase in lauryl phosphate concentration/adsorption density. It is expected that full monolayer coverage is achieved at $8.46 \mu \mathrm{mol} / \mathrm{m}^{2}$, with a sessile drop contact angle of $50^{\circ}$ and flotation recovery of $80 \%$.

4. Contact angle results from MDS with different levels of lauryl phosphate coverage, show that the bastnaesite surface becomes hydrophobic even at a low lauryl phosphate concentration of $2 \times 10^{-6} \mathrm{M}(8.3 \%$ coverage). These results are compared with an MDS contact angle of $0^{\circ}$ for octyl hydroxamate at a coverage of $8.3 \%$ as reported in the literature [1]. The MDS contact angle result of $41^{\circ}$ at $8.3 \%$ coverage of lauryl phosphate explains the improved performance of potassium lauryl phosphate as a collector for bastnaesite when compared to octyl hydroxamate at a low concentration $\left(\leq 5 \times 10^{-5} \mathrm{M}\right)[13]$.

\section{Acknowledgements}

Funding for this research by the Division of Chemical Sciences, Geosciences, and Biosciences, Office of Basic Energy Sciences of the U.S. Department of Energy through Grant No. DE-FG03-93ER14315 is gratefully acknowledged. Weiping's fellowship was provided by the China Scholarship Council (No. 201306370139). The Gaussian calculation and Amber MDS were enabled by the Center for High Performance Computing at the University of Utah. The authors would like to thank Dr. Anita M. Orendt for assisting with the Gaussian calculation, Dr. Thomas E. Cheatham, III, Dr. Xia Zhang, Dr. Jiaqi Jin and Daniel Roe for their assistance with Amber molecular dynamics simulations, Dr. Keith A. Prisbrey for assistance with the MOPAC 2012 calculations, and Ms. Dorrie Spurlock for her assistance with the preparation of the manuscript. 


\section{References}

[1] X. Zhang, H. Du, X. Wang, J.D. Miller, Surface chemistry aspects of bastnaesite flotation with octyl hydroxamate, Int. J. Miner. Process. 133 (2014) 29-38. doi:http://dx.doi.org/10.1016/j.minpro.2014.08.009.

[2] S.M. Bulatovic, Flotation of REO minerals, in: Handb. Flotat. Reagents Chem. Theory Pract. Flotat. Gold, PGM Oxide Miner., first ed., Elsevier Science, Amsterdam, NL, 2010: pp. 151-173.

[3] A. Jordens, Y.P. Cheng, K.E. Waters, A review of the beneficiation of rare earth element bearing minerals, Miner. Eng. 41 (2013) 97-114. doi:http://dx.doi.org/10.1016/j.mineng.2012.10.017.

[4] R. Houot, J.-P. Cuif, Y. Mottot, J.-C. Samama., Recovery of rare earth minerals, with emphasis on flotation process, Mater. Sci. Forum. 70-72 (1991) 301-304. doi:10.4028/www.scientific.net/MSF.70-72.301.

[5] Pradip, The surface properties and flotation of rare-earth minerals, Ph.D Thesis, University of California, Berkeley, CA, USA, 1981, 222 p.

[6] J. Zhang, B. Jian, An investigation of rare earth ore flotation using $\alpha$ stylphosphonic acid, Min. Metall. Eng. 2 (1981) 26-30.

[7] J. Zhang, X. Que, B. Jian, Collecting role of organic phosphoric acids on rareearths of Weishan, Nonferrous Met. 34 (1982) 29-32.

[8] G. Zhou, J. Luo, Mechanism of flotation using mono-alkyl ester phosphoric acid for bastnaesite, J. Chinese Rare Earth Soc. 8 (1990) 261-264.

[9] G. Zhou, J. Luo, Mechanism of flotation using citric acid for separating monazite from bastnaesite, Nonferrous Met. 41 (1989) 33-40.

[10] S. Chehreh Chelgani, B. Hart, L. Xia, A TOF-SIMS surface chemical analytical study of rare earth element minerals from micro-flotation tests products, Miner. Eng. 45 (2013) 32-40.

doi:http://dx.doi.org/10.1016/j.mineng.2013.01.011.

[11] K. Srinivas, T. Sreenivas, N.P.H. Padmanabhan, R. Venugopal, Studies on the application of alkyl phosphoric acid ester in the flotation of wolframite, Miner. Process. Extr. Met. Rev. 25 (2004) 253-267.

[12] A. Jordens, C. Marion, O. Kuzmina, K.E. Waters, Surface chemistry considerations in the flotation of bastnäsite, Miner. Eng. 66-68 (2014) 119129. doi:http://dx.doi.org/10.1016/j.mineng.2014.04.013.

[13] W. Liu, X. Wang, Z. Wang, J.D. Miller, Flotation chemistry features in bastnaesite flotation with potassium lauryl phosphate, Miner. Eng. 85 (2016) 17-22. doi:doi:10.1016/j.mineng.2015.10.010.

[14] D.D. Do, Adsorption Analysis: Equilibria and Kinetics, Imperial College Press, London, UK, 1998. doi:10.1142/9781860943829.

[15] J. Rouquerol, F. Rouquerol, P. Llewellyn, G. Maurin, K.S. Sing., Adsorption by Powders and Porous Solids: Principles, Methodology and Applications., Academic Press, Amsterdam, NL, 2013. doi:10.1016/B978-0-08-097035- 
6.00013-9.

[16] J. Drelich, E. Chibowski, D.D. Meng, K. Terpilowski, Hydrophilic and superhydrophilic surfaces and materials, Soft Matter. 7 (2011) 9804-9828. doi:10.1039/C1SM05849E.

[17] J. Drelich, J.D. Miller, R.J. Good, The effect of drop (bubble) size on advancing and receding contact angles for heterogeneous and rough solid surfaces as observed with sessile-drop and captive-bubble techniques, J. Colloid Interface Sci. 179 (1996) 37-50. doi:http://dx.doi.org/10.1006/jcis.1996.0186.

[18] A.C. Partridge, G.W. Smith, Small-sample flotation testing: a new cell, Trans. Inst. Min. Met. Sect. C. 80 (1971) C199.

[19] A. Ozkan, M. Yekeler, A new microscale flotation cell: combination of canadian column and partridge-smith cell, in: Proc. Seventeenth Int. Min. Congr. Exhib. Turkey, Ankara, 2001: pp. 759-763.

[20] A.K. Rappé, C.J. Casewit, K.S. Colwell, W.A. Goddard III, W.M. Skiff, UFF, a full periodic table force field for molecular mechanics and molecular dynamics simulations, J. Am. Chem. Soc. 114 (1992) 10024-10035.

[21] M.D. Hanwell, D.E. Curtis, D.C. Lonie, T. Vandermeersch, E. Zurek, G.R. Hutchison, Avogadro: an advanced semantic chemical editor, visualization, and analysis platform, J. Cheminform. 4 (2012) 1-17.

[22] J.J.P. Stewart, MOPAC2012. (2012). http://openmopac.net/.

[23] Z.A. Fekete, E.A. Hoffmann, T. Körtvélyesi, B. Penke, Harmonic vibrational frequency scaling factors for the new NDDO Hamiltonians: RM1 and PM6, Mol. Phys. 105 (2007) 2597-2605.

[24] A. Gonzalez-Lafont, T.N. Truong, D.G. Truhlar, Direct dynamics calculations with NDDO (neglect of diatomic differential overlap) molecular orbital theory with specific reaction parameters, J. Phys. Chem. 95 (1991) 4618-4627.

[25] J.J.P. Stewart, MOPAC online manual, (2016). http://openmopac.net/manual/sparkle.html.

[26] W. Humphrey, A. Dalke, K. Schulten, VMD: Visual molecular dynamics, J. Mol. Graph. 14 (1996) 33-38.

[27] Pradip, B. Rai, Molecular modeling and rational design of flotation reagents, Int. J. Miner. Process. 72 (2003) 95-110. doi:http://dx.doi.org/10.1016/S03017516(03)00090-5.

[28] P.O. Dral, X. Wu, L. Spörkel, A. Koslowski, W. Thiel, Semiempirical quantumchemical orthogonalization-corrected methods: benchmarks for ground-state properties, J. Chem. Theory Comput. 12 (2016) 1097-1120. doi:10.1021/acs.jctc.5b01047.

[29] D.A. Case, V. Babin, J.T. Berryman, R.M. Betz, Q. Cai, D.S. Cerutti, T.E.Cheatham. III, T.A. Darden, R.E. Duke, H. Gohlke, A.W. Götz, S. Gusarov, N. Homeyer, P. Janowski, J. Kaus, I. Kolossváry, A. Kovalenko, T.S. Lee, S. Le Grand, T. Luchko, R. Luo, B.D. Madej, K.M. Merz, F. Paesani, D.R. Roe, A. Roitberg, C. Sagui, R. Salomon-Ferrer, G. Seabra, C. Simmerling, W. Smith, J. 
Swails, R.C. Walker, J. Wang, R.M. Wolf, P.A. Kollman, AMBER 14, (2014).

[30] J. Jin, J.D. Miller, L.X. Dang, Molecular dynamics simulation and analysis of interfacial water at selected sulfide mineral surfaces under anaerobic conditions, Int. J. Miner. Process. 128 (2014) 55-67. doi:http://dx.doi.org/10.1016/j.minpro.2014.03.001.

[31] P.G. Kusalik, I.M. Svishchev, The spatial structure in liquid water., Science. 265 (1994) 1219-1221. doi:10.1126/science.265.5176.1219.

[32] M.W. Mahoney, W.L. Jorgensen, A five-site model for liquid water and the reproduction of the density anomaly by rigid, nonpolarizable potential functions, J. Chem. Phys. 112 (2000) 8910. doi:10.1063/1.481505.

[33] T. Werder, J.H. Walther, R.L. Jaffe, T. Halicioglu, P. Koumoutsakos, On the water-carbon interaction for use in molecular dynamics simulations of graphite and carbon nanotubes, J. Phys. Chem. B. 107 (2003) 1345-1352. doi:10.1021/jp0268112.

[34] J.E. Jones, On the determination of molecular fields. I. from the variation of the viscosity of a gas with temperature, Proc. R. Soc. A Math. Phys. Eng. Sci. 106 (1924) 441-462. doi:10.1098/rspa.1924.0081.

[35] H.J.C. Berendsen, J.R. Grigera, T.P. Straatsma, The missing term in effective pair potentials, J. Phys. Chem. 91 (1987) 6269-6271. doi:10.1021/j100308a038.

[36] G. Donnay, J.D.H. Donnay, The crystallography of bastnaesite, parisite, roentgenite, and synchisite, Am. Mineral. 38 (1953) 932-963.

[37] M.J. Frisch, G.W. Trucks, H.B. Schlegel, G.E. Scuseria, M.A. Robb, J.R. Cheeseman, G. Scalmani, V. Barone, B. Mennucci, G.A. Petersson, H. Nakatsuji, M. Caricato, X. Li, H.P. Hratchian, A.F. Izmaylov, J. Bloino, G. Zheng, J.L. Sonnenberg, M. Hada, M. Ehara, K. Toyota, R. Fukuda, J. Hasegawa, M. Ishida, T. Nakajima, Y. Honda, O. Kitao, H. Nakai, T. Vreven, J.A. Montgomery, J.E. Peralta, F. Ogliaro, M. Bearpark, J.J. Heyd, E. Brothers, K.N. Kudin, V.N. Staroverov, R. Kobayashi, J. Normand, K. Raghavachari, A. Rendell, J.C. Burant, S.S. Iyengar, J. Tomasi, M. Cossi, N. Rega, J.M. Millam, M. Klene, J.E. Knox, J.B. Cross, V. Bakken, C. Adamo, J. Jaramillo, R. Gomperts, R.E. Stratmann, O. Yazyev, A.J. Austin, R. Cammi, C. Pomelli, J.W. Ochterski, R.L. Martin, K. Morokuma, V.G. Zakrzewski, G.A. Voth, P. Salvador, J.J. Dannenberg, S. Dapprich, A.D. Daniels, Ö. Farkas, J.B. Foresman, J. V. Ortiz, J. Cioslowski, D.J. Fox, Gaussian 09, Gussian,Inc.,Wallingford, CT,USA. (2009).

[38] S. Melchionna, G. Ciccotti, B. Lee Holian, Hoover NPT dynamics for systems varying in shape and size, Mol. Phys. 78 (1993) 533-544.

[39] S.H. Lee, J.C. Rasaiah, Molecular dynamics simulation of ion mobility. 2. Alkali metal and halide ions using the SPC/E model for water at $25 \mathrm{C}$, J. Phys. Chem. 100 (1996) 1420-1425.

[40] K.F. Austen, K. Wright, B. Slater, J.D. Gale, The interaction of dolomite surfaces with metal impurities: a computer simulation study, Phys. Chem. Chem. Phys. 
7 (2005) 4150-4156.

[41] A.L. Rohl, K. Wright, J.D. Gale, Evidence from surface phonons for the $(2 \times 1)$ reconstruction of the (1014) surface of calcite from computer simulation, Am. Mineral. 88 (2003) 921-925.

[42] H. Yuehua, S. Wei, L. Haipu, Z. Xu, Role of macromolecules in kaolinite flotation, Miner. Eng. 17 (2004) 1017-1022. doi:10.1016/j.mineng.2004.04.012.

[43] T. Depci, Y. Onal, K.A. Prisbrey, Apricot stone activated carbons adsorption of cyanide as revealed from computational chemistry analysis and experimental study, J. Taiwan Inst. Chem. Eng. 45 (2014) 2511-2517. doi:10.1016/j.jtice.2014.05.015.

[44] Y. Hu, Z. Gao, W. Sun, X. Liu, Anisotropic surface energies and adsorption behaviors of scheelite crystal, Colloids Surfaces A Physicochem. Eng. Asp. 415 (2012) 439-448.

[45] B. Kronberg, K. Holmberg, B. Lindman, Surfactant adsorption at solid surfaces, in: Surf. Chem. Surfactants Polym., John Wiley \& Sons, Chichester, UK, 2014: pp. 159-166.

[46] E.C. Hunt, The interaction of alkyl phosphate monolayers with metal ions, J. Colloid Interface Sci. 29 (1969) 105-115. doi:http://dx.doi.org/10.1016/00219797(69)90352-X.

[47] X. Zhang, H. Du, X. Wang, J.D. Miller, Surface chemistry considerations in the flotation of rare-earth and other semisoluble salt minerals, Miner. Process. 30 (2013) 24-37.

[48] X. Zhang, Surface chemistry aspects of flourite and bastnaesite flotation systems, PhD. Thesis, University of Utah, Salt Lake City, UT, USA, 2014, 183 p. 


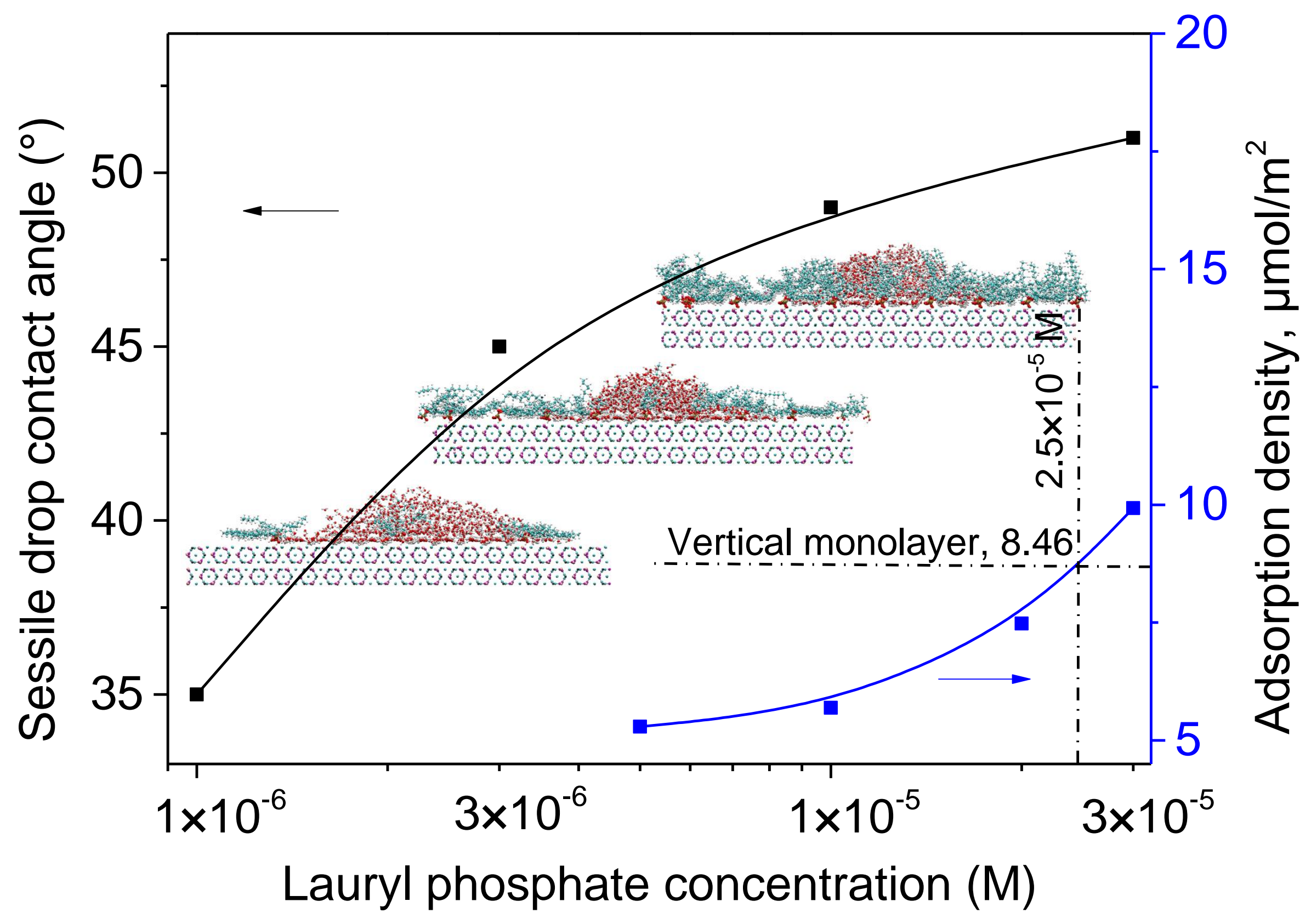

